\section{Sovereign wealth funds and corporate social responsibility: a comparison of Norway's Government Pension Fund Global and Abu Dhabi Fund for Development}

Sovereign wealth funds and CSR

\author{
Sivakumar Velayutham
}

Faculty of Business, Hospitality and Humanities, Nilai University,

Nilai, Malaysia, and

Rashedul Hasan

Faculty of Business and Law, Coventry University, Coventry, United Kingdom

\section{Abstract}

Purpose - The purpose of this paper is to critically discuss the participation of sovereign wealth funds (SWFs) in the corporate social responsibility (CSR) programmes. Sovereign wealth funds in emerging economies are often involved in corporate social responsibility. However, the 1 Malaysian Development Berhad (1MDB) scandal illustrates the possible use of SWF as a vehicle for corruption and abuse.

Design/methodology/approach - The primary objective is to develop good governance practices of CSR by SWFs that could limit corrupt practices. A case study approach is adopted to investigate the CSR involvement of two SWFs - Norway's Government Pension Fund Global (GPFG) and Abu Dhabi Fund for Development (ADFD).

Findings - The finding shows that SWFs should not be directly involved in CSR. It is proposed that independent Non-government Organisations (NGOs), through a competitive funding model, could serve the CSR purpose of SWFs more effectively and bring socio-economic changes in emerging economies.

Originality/value - The funding model identifies the expected outcomes, priorities and uses of the funds. The funding committee should also be independent of the Board and transparent in its allocations.

Keywords Sovereign wealth funds, corporate social responsibility, Governance, Accountability, Norway, Abu Dhabi

Paper type Research paper

\section{Introduction}

The Special Issue of Public Administration and Policy (Quah, 2020) highlights the extensive prevalence of systemic corruption in Asia. Whilst, many cases of corruption follow the frequently used methods of corruption, e.g., bribery, extortion, nepotism, fraud, and embezzlement, the 1 Malaysia Development Berhad (1MDB) scandal stands out because it

(C) Sivakumar Velayutham and Rashedul Hasan. Published in Public Administration and Policy. Published by Emerald Publishing Limited. This article is published under the Creative Commons Attribution (CCBY 4.0) license. Anyone may reproduce, distribute, translate and create derivative works of this article (for both commercial and non-commercial purposes), subject to full attribution to the original publication and authors. The full terms of this license may be seen at http://creativecommons. org/licences/by/4.0/legalcode

This study is funded by the Fundamental Research Grant Scheme (FRGS) offered by Malaysian Ministry of Higher Education (MOHE).
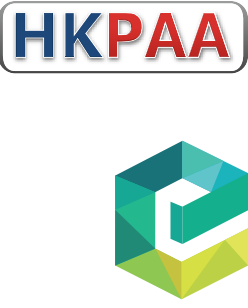

Public Administration and Policy Vol. 24 No. 2, 202 pp. 139-151 Emblishing Limited DOI 10.1108/PAP-08-2020-0037 
PAP

24,2

140

involves the use of sovereign wealth fund (SWF), corporate social responsibility (CSR), and its magnitude. The 1MDB scandal has been termed as "the world's biggest financial scandal" and "largest kleptocracy case" in the US history because the US Department of Justice believed that more than US $\$ 4.5$ billion was stolen from 1MDB (Ramesh, 2016). The 1MDB Malaysian SWF scandal has received global attention as investigations and charges have been filed against various individuals in more than ten countries around the world for money laundering and corruption. In 2015, Malaysia's then-Prime Minister Najib Razak was accused of channelling over RM2.67 billion (nearly USD700 million) from 1MDB to his bank accounts. Since Najib Razak departed as Prime Minister after losing the 2018 general election, he is facing more than 42 counts of corruption and money laundering charges (Bloomberg, 2019). It was revealed in court that a total of RM42 million from Ihsan Perdana (a CSR entity of 1MDB) made its way into two personal accounts of Najib between December 2014 and February 2015, in three tranches of RM27 million, RM5 million, and RM10 million (Chin, 2019).

Similarly, Velayutham and Hasan (2019) highlighted how a CSR project of Khazanah Nasional was disguised as a Public-Private Partnership to circumvent numerous conflicts of interest in Khazanah transactions. In this case, Khazanah Nasional, a SWF established in 1993 by the Malaysian Government initiated the Malaysian Trust School Program (TSP), a collaboration of Yayasan Amir (a foundation set up by Khazanah) and the Malaysian Ministry of Education to improve the access to quality education in public schools in 2010 (Yayasan Amir, 2017). The programme was funded by Yayasan Amir through Khazanah, other sponsors, and the issue of a Sukuk (Islamic Bonds), and was administered by Leap Ed (a wholly-owned subsidiary of Khazanah) by way of a service agreement with Yayasan Amir.

While CSR, as illustrated by the $1 \mathrm{MDB}$ and Khazanah Nasional cases above, is frequently a significant activity of SWFs and has been used to circumvent governance mechanisms for corruption purposes, it has received very little attention in the SWF governance literature. Such literature has mainly focussed on SWF investments in companies of target countries driven by politicians depicting SWFs as big, hostile, and uncontrollable (Gelpern, 2011). The outcome of the pressure was the development of the "Sovereign Wealth Funds: Generally Accepted Principles and Practices - Santiago Principles" (International Working Group of Sovereign Wealth Funds (IWG-SWF), 2008), the voluntary code of practice for SWFs. Since the impetus for the code was pressure from target countries, it mainly addressed their concerns. However, as highlighted by Gelpern (2011) as well as Gilson and Mailhaupt (2007), regulation of SWFs should focus on their activities in the host country as much as their activities in target countries.

This paper seeks to evaluate the CSR activities of two major SWFs with extensive CSR activities - Norway's Government Pension Fund Global (GPFG), and Abu Dhabi Fund for Development (ADFD). The GPFG is the largest SWF in the world; and the sister organisation of ADFD, the Abu Dhabi Investment Authority is the third largest SWF in the world. Both funds were set up to manage the oil wealth of the two states. Whilst they have many similarities, they are also very different in how the two countries are governed - in the case of Norway, a democracy, and Abu Dhabi an absolute monarchy.

The rest of the paper is organised as follows. The next section defines SWFs and provides a brief literature review of the governance of SWFs. Then, it reviews the CSR literature and documents the CSR activities of several SWFs around the world. The last section evaluates the CSR activities and their governance of CSR activities, identifying best practices, ended with concluding remarks.

\section{Regulation of sovereign wealth funds}

The Sovereign Wealth Funds: Generally Accepted Principles and Practices define SWFs as "special purpose investment funds or arrangements that are owned by the general government” (IWG-SWF, 2008, p.3). The definition explicitly excludes "foreign currency 
reserve assets held by monetary authorities for the traditional balance of payments or monetary policy purposes, state-owned enterprises (SOEs) in the traditional sense, government-employee pension funds, or assets managed for the benefit of individuals" (IWG-SWF, 2008, p.3). These investment vehicles are usually funded by commodity export revenues or the transfer of assets directly from official foreign exchange reserves. In some cases, government budget surpluses and pension surpluses have also been transferred into SWFs (Butt et al., 2008). More recently, however, many SWFs have resorted to debt to help finance their investment activities (Bertoni and Lugo, 2017).

Al Hassan et al. (2013) have identified five types of funds based on their objectives, namely:

1. stabilisation funds - set up to insulate the budget and economy from commodity price volatility and external shocks (e.g., Chile's Economic and Social Stabilization Fund)

2. savings fund - set up to share wealth across generations by transforming nonrenewable assets into diversified financial assets (e.g., Abu Dhabi Investment Authority)

3. development fund - established to allocate resources to priority socio-economic projects, usually infrastructure (e.g., UAE's Mubadala)

4. pension reserve funds - set up to meet identified outflows in the future concerning pension-related contingent-type liabilities on the government's balance sheet (e.g., Malaysia's KWAP)

5. reserve investment corporations - to reduce the negative carry costs of holding reserves or to earn a higher return on ample reserves, while the assets in the funds are still counted as reserves (e.g., China, South Korea, and Singapore)

The first state SWF was established in 1953 by Kuwait and started as an operation to manage the country's oil revenue surpluses through a London office. In 1983, it was officially established as a public government entity called the Kuwait Investment Authority (KIA) (Alhashel, 2015). Today there are more than 89 SWFs managing assets worth more than US\$8.4 trillion (Sovereign Wealth Fund Institute, 2019). Currently, the largest SWF is the Norway Government Pension Fund Global with total assets of about US $\$ 1.2$ trillion.

The growing number of assets managed by SWFs has caught increasing worldwide attention. Such prominence has brought a host of ethical and social issues, ranging from the responsibility to balance between the interests of different stakeholders who might sometimes be conflicting to intergenerational competition for resources (Bischoff and Wood, 2019).

Early calls for regulation of SWFs were mainly from host countries of SWF investments. The first calls started in early 2000 when the Dubai Ports World (DPW), a state-owned entity was supposed to manage six US ports as a result of its acquisition of a British company (US Department of Treasury, 2006), and the China National Offshore Oil Corporation (CNOOC) bid for the US oil company Unocal (Knowledge@Wharton, 2005). These outcries have been accompanied by demands for significant regulation of SWFs in target countries and greater transparency on the part of the SWFs.

Gilson and Mailhaupt (2007) note that the controversy regarding the SWF equity investments that allow them to become significant controllers of the firm is a bit exaggerated. Rose (2009) argues that if SWFs wanted to make their investments politically driven instead of economically driven, there are various regulatory, economic, and political effects mitigating such risks. Rose further asserts that the US does not need more regulation but rather continued vigilance to protect the US from any possible political threats from SWFs. The argument against additional or excessive regulation is further supported by Santiso and Avendano (2010), Bahgat (2008), and Epstein and Rose (2009).

Sovereign wealth funds and CSR 
The SWFs, however, had to respond to the pressure. In 2008, to address these concerns, a joint effort between the International Monetary Fund (IMF) and the "International Working Group of Sovereign Wealth Funds (IWG-SWF)" was formed. This collaboration represents the coming together of 14 principle funds including some of the largest, such as GIC Private Limited and Abu Dhabi Investment Authority, drafted the 24 Santiago Principles, to set out common international standards regarding transparency, independence, and governance which SWFs might follow (IWG-SWF, 2008). These were made public after being presented to the IMF International Monetary Financial Committee on 11 October, 2008. Behrendt (2011a) found that the implementation of the Santiago Principles remains fragmented with a compliance rate between 50 and 60 percent.

The activities of SWFs are as controversial in the host country as much as target countries and hence regulation of SWFs should focus on their activities in the host country as much as their activities in target countries (Gelpern, 2011; Gilson and Mailhaupt, 2007). For example, the 1982 law that established the Kuwait Investment Authority (KIA) prohibits disclosure to the public of any information related to KIA's work, including the value of its assets under management. The Iraq invasion of Kuwait and the subsequent reconstitution of a new parliament led to the disclosure of massive asset losses within KIA due to corruption and theft leading to the promulgation of a new law requiring KIA to report to the parliament twice a year on all significant state investments (Murphy, 1993).

Gilson and Mailhaupt (2007) argue that the controversies of regulating SWFs are caused by the friction of two concepts, state capitalism and market capitalism. Market capitalism is defined by minimal government intervention in the economy and by individual firms whose objective is to maximise their value. On the other hand, state capitalism is concerned with maximising the value of a country's economy as a whole and is characterised by a government that has a significant role in the economy. Frequently the management of SWFs has attempted to exploit the flexibility provided by each governance mechanism to minimise scrutiny.

Gelpern (2011) argues that transnational hybrids such as SWFs face a four-fold challenge: they are accountable to constituencies at home and abroad; to the public at large; and a narrower set of stakeholders defined by their organisational form and business practices. Based on the above, Gelpern (2011) identifies four dimensions or axis of accountability: (a) internal public accountability - achieved within the political system of the capital-exporting state; (b) private internal accountability -SWFs' duties to a subset of shareholders, creditors, or other stakeholders, which stem predominantly from their charters and contracts; (c) external public accountability - duty of state-owned funds to adhere to international norms; and (d) private external accountability - describes SWFs as subjects of host country laws and norms applicable to private market participants. This study focuses on the internal public accountability of SWFs.

This section begins by defining the concept of the sovereign wealth funds (SWFs). The authors have classified various sources of SWFs and provided a brief historical overview of SWF development. It is important to explore the origin, purpose and development of SWFs before identifying the limitations restricting the potential of such a development fund's contribution to economic development. Critical review of past studies reveals a lack of regulation of SWFs in host countries. Such trend is prominent in either oil-rich monarchy, e.g., Kuwait, Abu Dhabi, Qatar; autocracies, e.g. Russia and China; and democracies dominated by a single political party, e.g. Singapore and Malaysia (Behrendt, 2011b). Scrutiny of SWFs is also frequently depicted by politicians in the host as undermining national champions (Velayutham, 2016). Therefore, this study contributes to the literature by examining the CSR aspect inherent in the SWF. The next section will explore the theoretical and practical aspects of the CSR model of SWFs to cater to the socio-economic issues eminent in emerging economies. 


\section{Corporate social responsibility of sovereign wealth funds}

CSR has always been a controversial topic with arguments for and against it (Carroll and Shabana, 2010). The case against CSR frequently begins with the classical economic argument made by Milton Friedman in the late 1970s, i.e., management has one responsibility, and that is to maximise the profits of its owners or shareholders. Friedman (1970) argued that social issues are not the concern of business people and that these problems should be resolved by either the unfettered workings of the free market system; or if the free market cannot solve the social problems, it falls upon government and legislation to do the job. He also observes that business is not the best institution equipped to handle social activities. It is also pointed out that shareholders, rather than managers, should be the right decision-makers on social activities.

The agency view makes the case that investment in CSR is simply a representation of agency problems within the firm and would be value-destroying. Bénabou and Tirole (2010) argue that in cases where CSR is initiated by management, it comes at a cost to corporations. Masulis and Reza (2014) found that a high percentage of firms contribute to charitable organisations affiliated in some manner with the CEO. They found several instances where CSR appears to benefit the CEO in some ways, and thus that corporate philanthropy is not just a way to maximise the firm's value; agency problems between managers and shareholders come into play. The above supports the argument of Behrendt (2011b) that SWFs managed by authoritarian governments are distinguished by a lack of public oversight and are instead tightly controlled by the current political leadership, and this allows governments more flexibility in using financial assets to pursue immediate political agendas.

Arguments in favour of CSR are based on the belief that it is in a business's long-term selfinterest to be socially responsible. The standard explanation for why company invests in CSR is that doing so enhances profitability and its company value; a relationship often referred to as "doing well by doing good" (Dowell et al., 2000; Orlitzky et al., 2003; Renneboog et al., 2008a; Renneboog et al., 2011; Krueger, 2015). Other studies consider the inverse, that is, "doing good by doing well," by examining whether it is only well-performing firms that can afford to invest in CSR (Hong et al., 2012). The third argument in favour of CSR is that it will ward off government regulation. Liang and Renneboog (2017), for example, found that there is a strong link between firm-level CSR and country-level legal origin, which may help explain crosscountry variation in CSR.

CSR focuses on the way firms conduct business, whereas Socially Responsible Investing (SRI) encompasses the judgment of potential investments on specific social and ethical criteria in portfolio management. If more and more funds adopt SRI practices, it is argued that this will put pressure on firms to incorporate CSR into decision-making (Sparkes and Cowton, 2004). SRI becomes relevant in the screening of investments, where managers evaluate possible target firms on whether they adhere to specific CSR standards (Renneboog et al., 2008b).

The prominence of SWFs in their home country requires them to maintain their legitimacy in both the home countries as well as investment destination countries. To maintain their legitimacy, they have frequently embarked on CSR activities and socially responsible investments. A review of the top ten SWFs (Sovereign Wealth Fund Institute, 2019) found that only one is located in Europe (Norway Government Pension Fund Global (Norway GPFG)) and the rest are located in Asia or the Middle East. SRI has not been a significant issue or concern in Asia or the Middle East, and hence only Norway GPFG has clear policies on SRI. The other top ten SWFs have no clear statement on SRI but rather have extensive statements on their CSR activities.

The other top SWFs reports mainly focus on their CSR activities. The Kuwait Investment Authority's (KIA) (the oldest and fourth-biggest SWF) main CSR program
Sovereign wealth funds and CSR 
involves training programs predominantly for locals but also regional capacity development. These mainly include MBA scholarships, and the IMF Middle East Centre for Economics and Finance (Kuwait Investment Authority, 2019). The China Investment Corporation (CIC), the second biggest SWF is involved in various poverty eradication efforts in various provinces in China (China Investment Corporation, 2018). In the case of the Abu Dhabi Investment Authority (ADIA) the third-largest fund, there is little information on its CSR activities. However, the Abu Dhabi government has established a separate Abu Dhabi Fund for Development with a mission to help developing countries to achieve sustainable economic growth and reduce poverty. It does this by providing concessionary financial resources in the form of loans.

Closer to Malaysia, Singapore owned SWF, Temasek Holdings has established the Temasek Foundation to deliver community programs in Singapore and Temasek Trust to provide governance and financial oversight for the endowment beneficiaries. Another Singapore owned SWF, the Government Investment Corporation also the sixth-largest SWF has funded several CSR projects like the Sparks and Smiles and the Purple Symphony.

\section{CSR by Norway's GPFG and Abu Dhabi's ADFD}

The problem of CSR by SWFs is similar to the controversies of regulating SWFs which is caused by the friction of two concepts, public governance and corporate governance. The merits of public governance and corporate governance have been discussed extensively, and each has been ascendant at different times (Benz and Frey, 2007; Hirigoen and Laouer, 2013). In the early 1980s, the New Public Management literature advocated the adoption of the market and corporate practices by government entities (Gruening, 2001). These practices were first adopted in the United Kingdom under Prime Minister Margaret Thatcher and in the municipal governments in the US (e.g., Sunnyvale, California) that had suffered heavily from economic recession and tax revolts. The significant characteristics included privatisation and competition in public service provision, customer focus, decentralisation and the separation of funding and provision of services (Stewart and Walsh, 1992; Borins, 1995; Boston et al., 1996).

Following the global financial crisis, Benz and Frey (2007) argue that corporate governance can learn from public governance. Institutions devised to control and discipline the behaviour of executives in the political sphere which can give new insights on how to improve the governance of firms. Hirigoen and Laouer (2013) argue that there is a convergence of corporate and public governance. The difference between public and corporate governance stems from the objectives of each. The objectives of corporate governance are particular and measurable, i.e. shareholder wealth maximisation (Friedman, 1970); in contrast to the objectives of public governance which is more nebulous and therefore has no precise measurement, i.e., public wellbeing. Because the corporate governance objectives are more specific and measurable, the executive is given more freedom to achieve the objectives; in contrast, public governance has mainly been about control. Light (1993) points out that this term has long been narrowly defined as "limit[ing] bureaucratic discretion through compliance with tightly drawn rules and regulations" (p.12).

As pointed out earlier SWFs are hybrids and hence appear to frequently not having such clear objectives because they are controlled by the state and funded from public funds, but with freedom of corporates, hence SWFs becoming a significant preference of autocratic regimes, providing them with considerable scope for corruption and abuse. SWFs should be responsible for investing in tax-payers funds effectively, and the returns on the investment should be returned to the government for allocation to public interest projects which do not seem to happen in many countries with SWFs. 
Government Pension Fund Global (GPFG)

The GPFG was established in 1990 through an Act of parliament to shield the economy from ups and downs in oil revenue. It also serves as a financial reserve and as a long-term savings plan so that both current and future generations get to benefit from the oil wealth. Whilst, the first money was transferred in 1996, it grew rapidly to become the world's largest SWF with total assets of US\$1.2 trillion. The fund is managed by the Norges Bank Investment Management. The GPFG does not have CSR activities but rather practices Responsible Investments, i.e., CSR is subsumed in its investment practices. The GPFG has seven major sustainable expectations (based on internationally recognised principles such as the UN Global Compact, the UN Guiding Principles on Business and Human Rights, the G20/OECD Principles of Corporate Governance, and the OECD Guidelines for Multinational Enterprises) of all companies it invests (Norges Bank, 2021):

1. Protection of children's rights - companies to respect children's rights in their business operations and supply chains, community interactions and the marketing and use of their products and services;

2. Climate change - companies to pursue sustainable policies and disclosure the climate impact of their activities;

3. Water management - effective management of water sustainability and risks;

4. Human rights - respect for human rights in all business activities;

5. Tax transparency - companies to avoid aggressive tax behaviour and be transparent about where they generate economic value;

6. Anti-corruption - companies to identify and manage corruption risk, and to report publicly on their anti-corruption effort;

7. Sustainable use of the ocean - companies to have policies and practices to minimise the degradation of the ocean.

The Fund has detailed published expectations of companies for each of its seven major expectations which is available on its website (https://www.nbim.no/en/publications/). All seven documents require companies to:

1. Integrate expectation into policies and strategies;

2. Integrate expectation risk into risk management;

3. Disclose material expectation information;

4. Engage transparently and responsibly on the expectation.

Based on the above expectations, the Ministry of Finance has developed a set of Ethical Guidelines for the observation and exclusion of companies from the Funds Portfolio to be implemented by a Council on Ethics, which is appointed and reports independently to the Ministry of Finance. The role of the Council on Ethics for the Government Pension Fund Global (GPFG) is to evaluate whether or not the Fund's investment in specified companies is inconsistent with its Ethical Guidelines. The guidelines contain both product-based exclusion criteria, such as the production of tobacco, coal or certain types of weapons, and conduct-based exclusion criteria, such as corruption, human rights violations, environmental damage and unacceptably high greenhouse gas emissions. The Council consists of five members and is supported by a secretariat. The Council's recommendations on the companies to be excluded are published on the Council's
Sovereign wealth funds and CSR 
PAP

24,2

website including the reasons for the exclusion (Council on Ethics, 2020). In addition to the above disclosures, Norges Bank also publishes its investment in all the individual companies, allowing scrutiny by the public.

\section{The Abu Dhabi Fund for Development (ADFD)}

The Abu Dhabi Fund for Development (ADFD) was established in 1971 to help developing countries to achieve sustainable economic growth and reduce poverty (Abu Dhabi Fund for Development, 2020). To do so it provides concessionary financial resources in the form of sovereign loans. In 2019 for example the fund provided US $\$ 1.2$ billion in concessionary loans and US $\$ 235$ million in development grants. The fund is administered by a Board of Directors that is responsible for directing and supervising the fund's development and investment activities, including deciding on its lending requests, identifying investments and applying corporate governance.

The ADFD publishes its guidelines on the submission of funding applications, funding eligibility and funding process on its website (https:/www.adfd.ae/english/Pages/Home. aspx). The ADFD only accepts funding applications from mainly government entities and semi-government entities or private companies with a government guarantee. The application must be for an infrastructure project, e.g., energy, water, transportation, health, housing or education; from a developing country; and the project must fall within the government's developmental priorities, and the project must have a positive socio-economic impact. Also, requests need to be supported by an economic feasibility study and projected cash flows.

The funding process has identified steps that include:

1. Review of application documents

2. Initial assessment

3. Project appraisal

4. Loan approval

The Fund publishes the projects that have been funded including a brief description, the year, and the country. The ADFD Annual report 2019 includes individual projects funded in the year including the amount, the type of funding, e.g., concessionary loans, grants.

\section{Best practices}

The two cases illustrate major differences in approach but many similarities in practices that provide a basis for the development of best practices. The major difference is that CSR is subsumed in GPFG's investment policies while CSR is practised separately and independently of its investment policy. A review of SWFs, as well as private companies' practices, would indicates that the second approach is more common because the fund is free to maximise the returns on its investment regardless of the sustainability or ethics of the companies it invests in. CSR from this perspective is used as a means of cleansing its sins or corporate conscience. Also, to practising an investment policy that is based on ethics and sustainability, the Council on Ethics of the GPFG is promoting and facilitating CSR globally through its practice of publishing the names and reasons for companies excluded from its portfolio - a form of naming and shaming companies to encourage them to be more sustainable and ethical, i.e., promoting CSR through investments and negative sanctions.

The review of the CSR activities of GPFG and ADFD also highlights several best practices that should be adopted by SWFs in their CSR activities to minimise conflicts of interest and corruption. First, in GPFG and ADFD, the SWF is separated from the CSR funder or CSR guardian, and the CSR funder does not report to the SWF. As pointed out 
earlier in Abu Dhabi, the SWF is the Abu Dhabi Investment Authority, and the CSR arm of Abu Dhabi is the ADFD and both reports independently to the government. In the case of Norway, the SWF is Norway GPFG managed by Norges Bank, and the implementer of its SRI framework is the Council on Ethics, each appointed and reports independently to the Ministry of Finance.

The second characteristic is that they fund CSR projects but do not operate the CSR projects, i.e., they are not directly involved in delivering CSR because the scope for abuse is unlimited. In the case of ADFD, it does not deliver CSR but funds CSR and in the case of the GPFG, it practices Socially Responsible Investments (SRI). Besides, the GPFG does not take controlling stakes in companies but rather small investments. In the case of ADFD its funding can be in the form of investment in companies that play a vital role in stimulating economic growth and creating job opportunities, and development funding through long term development loans with concessionary interest rates. The two organizations also focus on CSR that that is sustainable, i.e., the projects or investment do not require continuous cash infusion as in the case of the Trust School project, but rather selfsustaining and frequently able to return the initial investment which could be used to fund new CSR projects.

The third characteristic is that they have clear criteria for funding. Both ADFD and GPFG have explicitly stated criteria. In the case of ADFD, the application must be for an infrastructure project, e.g., energy, water, transportation; from a developing country; project falls within the government's developmental priorities; and requests need to be supported by an economic feasibility study and projected cash flows. In the case of GPFG, the guidelines for observation and exclusion have explicit statements and targets, e.g., observation or exclusion may be decided for mining companies and power producers which themselves or through entities, they control and derive 30 percent or more of their income from thermal coal (Norwegian Government Security and Service Organisation, 2019).

Fourth, both the GPFG and ADFD have transparent funding or investment process which includes deadlines for applications, assessment and approvals for the ADFD. In the case of the ADFD, it also gets involved in project management through direct supervision. The $\mathrm{ADFD}$ fund recipients are expected to provide progress and final reports on how the money was spent and benefits to society. In the case of the GPFG, Norges Bank has published voting principles and guidelines that it practices at company AGMs and in some cases publishes its voting intentions ahead of AGMs.

Fifth, there is a public announcement of the recipients and the amount awarded. The Norway GPFG reports Fund's investments by country, asset class and sector and the individual companies. Similarly, the Council on Ethics reports on all excluded companies in its annual report.

\section{Conclusion}

Most SWFs are involved in CSR, but as the 1 Malaysian Development Berhad (1MDB) scandal illustrates that it can also be a vehicle for corruption and abuse. The abuse of CSR has received very little attention in the SWF governance literature because the SWF governance literature has mainly focused on the regulation of foreign direct investments by SWFs. The paper highlights the primary reason for this is that the scrutiny of SWFs has mainly been by countries receiving investments by SWFs and minimal scrutiny at home because many of the SWFs are located in either oil-rich monarchy, e.g., Kuwait, Abu Dhabi, Qatar; autocracies, e.g. Russia and China; and democracies dominated by a single political party, e.g. Singapore and Malaysia (Behrendt, 2011b). Scrutiny of SWFs is also frequently depicted by politicians in a host as undermining national champions. 
PAP

24,2

148

This paper is based on an in-depth study of CSR involvement of two SWFs - GPFG and ADFD seek to develop good governance practices of CSR by SWFs and remedy the deficit in the SWF governance literature. It is recommended that the SWF should be separated from the CSR funder, and the CSR funder should not have primary accountability to the SWF. While SWFs can serve as the funding source for the CSR project, it is recommended that SWFs do not operate the CSR projects to ensure an optimum level of fund utilization. However, CSR projects need to have clear criteria for funding. SWFs also have the responsibility to ensure a transparent funding process preferably through a competitive process. SWFs could improve the transparency of the funding process by making such information publicly accessible. Findings and policy recommendation provided in this study could serve as a guidance mechanism for the regulatory authority. SWFs have a much bigger role to bring positive socio-economic change for emerging economies and the effective use of the CSR function can foster such change through the participation of both government and non-government agencies.

\section{References}

Abu Dhabi Fund for Development (2020), "Our history", available at: https://www.adfd.ae/english/ ABOUTADFD/OurHistory/Pages/history.aspx (accessed 15 February 2021).

Alhashel, B. (2015), "Sovereign wealth funds: a literature review", Journal of Economics and Business, Vol. 78 No. C, pp. 1-13.

Al-Hassan, A., Papaioannou, M., Skancke, M. and Sung, C.C. (2013), "Sovereign wealth funds: aspects of governance structures and investment management", Working paper WP/13/231, International Monetary Fund, Washington, D.C.

Bahgat, G. (2008), "Sovereign wealth funds: dangers and opportunities", International Affairs, Vol. 84 No. 6, pp. 1189-1204.

Behrendt, S. (2011a), "The Santiago Principles: a voluntary code for Sovereign Wealth Funds", in Park, D. (Ed.), Sovereign Asset Management for a Post-Crisis World, Central Banking Publications, London.

Behrendt, S. (2011b), "Sovereign Wealth Funds in nondemocratic countries: financing entrenchment or change?", Journal of International Affairs, Vol. 65 No. 1, pp. 65-78.

Bénabou, R. and Tirole, J. (2010), "Individual and corporate social responsibility", Economica, Vol. 77 No. 305 , pp. 1-19.

Benz, M. and Frey, B.S. (2007), “Corporate governance: what can we learn from public governance?”, Academy of Management Review, Vol. 32 No. 1, pp. 92-104.

Bertoni, F. and Lugo, S. (2017), "The use of debt by sovereign wealth funds", in Cummings, D., Wood, G., Filatotchev, I. and Reinecke, J. (Eds), The Oxford Handbook of Sovereign Wealth Funds, Oxford University Press, Oxford, pp. 274-298.

Bischoff, C. and Wood, G. (2019), "SWFs and Corporate Social Responsibility", in Rettab, B. and Mellahi, K. (Eds), Practising CSR in the Middle East, Palgrave Macmillan, Cham, pp. 83-99.

Bloomberg (2019), "A long list of charges against Najib as 1MDB trial kicks off on Tuesday", The Straits Times, available at: https://www.straitstimes.com/asia/se-asia/a-long-list-of-chargesagainst-najib-as-1mdb-trial-kicks-off-on-tuesday (accessed 11 February 2020).

Borins, S. (1995), “The New Public Management is here to stay", Canadian Public Administration, Vol. 38 No. 1, pp. 122-132.

Boston, J., Martin, J., Pallot, J. and Walsh, P. (1996), Public Management: The New Zealand Model, Oxford University Press, Auckland.

Butt, S., Shivdasani, A., Stendevad, C. and Wyman, A. (2008), "Sovereign wealth funds: a growing global force in corporate finance", Journal of Applied Corporate Finance, Vol. 20 No. 1, pp. 73-83. 
Carroll, A.B. and Shabana, K.M. (2010), "The business case for corporate social responsibility: a review of concepts, research and practice", International Journal of Management Reviews, Vol. 12 No. 1, pp. 85-105.

Chin, E.S.M. (2019), "SRC trial: Ihsan Perdana a shelf company buyout, rebranding to handle 1MDB's CSR projects", Malay Mail, available at: https:/www.malaymail.com/news/malaysia/2019/05/15/ src-trial-ihsan-perdana-a-shelf-company-buyout-rebranding-to-handle-1mdbs-c/1753216 (accessed 15 May 2020).

China Investment Corporation (2018), "Annual Report 2018, China Investment Corporation, China”, available at: http://www.china-inv.cn/chinainven/Media/Annual_Report.shtml (accessed 15 May 2020).

Council on Ethics (2020), "Recommendations", available at: https:/etikkradet.no/recommendations/ (accessed 15 February 2021).

Dowell, G., Hart, S. and Yeung, B. (2000), "Do corporate global environmental standards create or destroy market value?", Management Science, Vol. 46 No. 8, pp. 1059-1074.

Epstein, R.A. and Rose, A.M. (2009), "The regulation of sovereign wealth funds: the virtues of going slow", University of Chicago Law Review, Vol. 76 No. 1, pp. 111-134.

Friedman, M. (1970), "The social responsibility of business is to increase its profits", New York Times, 13 September, p. 17.

Gelpern, A. (2011), "Sovereignty, accountability, and wealth fund governance conundrum", Asian Journal of International Law, Vol. 1 No. 2, pp. 289-320.

Gilson, R.J. and Milhaupt, C.J. (2007), “Sovereign wealth funds and corporate governance: a minimalist response to the new mercantilism", Stanford Law Review, Vol. 60 No. 5, pp. 1345-1370.

Gruening, G. (2001), "Origin and theoretical basis of New Public Management”, International Public Management Journal, Vol. 4 No. 1, pp. 1-25.

Hirigoyen, G. and Laouer, R. (2013), "Convergence of corporate and public governance: Insights from board process view”, Sage Open, Vol. 3 No. 2, pp. 1-8.

Hong, H., Kubik, J.D. and Scheinkman, J.A. (2012), "Financial constraints and corporate goodness", NBER Working Paper No. 18476, National Bureau of Economic Research, Cambridge.

International Working Group of Sovereign Wealth Funds (IWG-SWF) (2008), "Sovereign Wealth Funds: Generally Accepted Principles and Practices 'Santiago Principles", available at: https:// www.ifswf.org/santiago-principles (accessed 15 February 2021).

Knowledge@Wharton (2005), “Is CNOOC's bid for Unocal a threat to America?”, available at: http:// knowledge.wharton.upenn.edu/article.cfm?articleid=1240 (accessed 15 February 2021).

Krueger, P. (2015), “Corporate goodness and shareholder wealth", Journal of Financial Economics, Vol. 115 No. 2, pp. 304-329.

Kuwait Investment Authority (2019), “Training Programme”, available at: https://kia.gov.kw/trainingprograms/ (accessed 15 February 2021).

Liang, H. and Renneboog, L. (2017), "On the foundations of corporate social responsibility", The Journal of Finance, Vol. 72 No. 2, pp. 853-910.

Light, P.C. (1993), Monitoring Government: Inspectors General and the Search for Accountability, Brookings Institution, Washington, D.C.

Masulis, R.W. and Reza, S.W. (2014), "Agency problems of corporate philanthropy", The Review of Financial Studies, Vol. 28 No. 2, pp. 592-636.

Murphy, K. (1993), "\$5-Billion loss riles even Oil-Rich Kuwaitis; scandal: Parliament's Probe of public funds poses the most serious challenge ever to the ruling family's power", Los Angeles Times, 10 February.

Norges Bank (2021), "Government Pension Fund Global”, available at: https://www.nbim.no/en/ (accessed 10 June 2021). 
PAP

24,2

Norwegian Government Security and Service Organisation (2019), "Guidelines for Observation and Exclusion from the Government Pension Fund Global", available at: https:/nettsteder. regjeringen.no/etikkradet3/files/2019/12/guidelines-for-observation-and-exclusion-from-thegpfg-01.09.2019.pdf (accessed 15 February 2021).

Orlitzky, M., Schmidt, F.L. and Rynes, S.L. (2003), “Corporate social and financial performance: a metaanalysis”, Organisation Studies, Vol. 24 No. 3, pp. 403-441.

Quah, J.S.T. (2020), "Corruption scandals in six Asian countries: a comparative analysis", Public Administration and Policy, Vol. 23 No. 1, pp. 7-21.

Ramesh, R. (2016), "1MDB: the inside story of the world's biggest financial scandal", The Guardian, 28 July, available at: https:/www.theguardian.com/world/2016/jul/28/1mdb-inside-story-worldsbiggest-financial-scandal-malaysia (accessed 10 June 2021).

Renneboog, L., Ter Horst, J. and Zhang, C. (2008a), "The price of ethics and stakeholder governance: the performance of socially responsible mutual funds", Journal of Corporate Finance, Vol. 14 No. 3, pp. 302-322.

Renneboog, L., Ter Horst, J. and Zhang, C. (2008b), "Socially responsible investments: institutional aspects, performance and investor behaviour", Journal of Banking and Finance, Vol. 32 No. 9, pp. 1723-1742.

Renneboog, L, Ter Horst, J. and Zhang, C. (2011), "Is ethical money financially smart? Nonfinancial attributes and money flow of socially responsible investment funds", Journal of Financial Intermediation, Vol. 20 No. 4, pp. 562-588.

Rose, P. (2009), "Sovereign wealth fund investment in the shadow of regulation and politics", Georgetown Journal of International Law, Vol. 40 No. 4, pp. 1207-1238.

Santiso, J. and Avendano, R. (2010), "Are sovereign wealth fund investments politically biased? Comparing mutual and sovereign funds", available at: https://voxeu.org/article/are-sovereignwealth-fund-investments-politically-biased (accessed 10 June 2021).

Sovereign Wealth Fund Institute (2019), “Top 89 Largest Sovereign Wealth Fund Rankings by Total Assets", available at: https://www.swfinstitute.org/fund-rankings/sovereign-wealth-fund (accessed 15 February 2021).

Sparkes, R. and Cowton, C.J. (2004), "The maturing of socially responsible investment: a review of the developing link with corporate social responsibility", Journal of Business Ethics, Vol. 52 No. 1, pp. $45-57$.

Stewart, J. and Walsh, K. (1992), "Change in the management of public services", Public Administration, Vol. 70 No. 4, pp. 499-518.

US Department of Treasury (2006), "CFIUS and the Protection of the National Security in the Dubai Ports World Bid for Port Operations", available at: https:/www.treasury.gov/press-center/ press-releases/Pages/js4071.aspx (accessed 15 February 2021).

Velayutham, S. (2016), "National champions in a global arena: rhetoric and inequality in global capitalism", in Sprague, J. (Ed.), Globalisation and Transnational Capitalism in Asia and Oceania, Routledge, London, pp. 139-156.

Velayutham, S. and Hasan, R. (2019), "The Malaysian Trust School Programme: Is it a PublicPrivate Partnership (PPP)?”, Asian Review of Public Administration, Vol. 30 Nos 1 \& 2, pp. $42-53$.

Yayasan Amir (2017), Yayasan Amir Trust Schools Programme Annual Progress Report 2016, Yayasan Amir, Kuala Lumpur.

\section{About the authors}

Sivakumar Velayutham is Professor in the Faculty of Business, Hospitality and Humanities, Nilai University, Malaysia. He has many years of working experience at a number of top universities in Australia, New Zealand, United Arab Emirates and Oman. Prior to joining Nilai University, he was Professor of Accounting at Charles Darwin University in Australia. He has also published more 
than 30 papers in peer-reviewed journals indexed in ABS, ABDC and SCOPUS. His research interests include corporate governance, accounting education, conventional and Islamic accounting issues.

Rashedul Hasan is a Lecturer in Accounting at Coventry University, United Kingdom. He completed his $\mathrm{PhD}$ in 2018, which focuses on corporate governance issues for a non-profit organization. He is also a CIMA member and holds the designation of ACMA, CGMA. His research interests include corporate governance dynamics, performance, and risk management aspects of financial institutions, sustainability, and accountability issues. He is serving as the Associate Editor of the Journal of Economic Cooperation and Development. He has been publishing research in ABS, ABDC, and SCOPUS indexed accounting and finance journals. Rashedul Hasan is the corresponding author and can be contacted at: hasanaiub05@gmail.com

\section{Sovereign wealth funds and CSR}

For instructions on how to order reprints of this article, please visit our website: 